This is the pre-peer reviewed version of the following article: Sagner, J. S. (2008), Financial Regulation: What Should Be Done? J. Corp. Acct. Fin., 19: 25-31. doi: 10.1002/jcaf.20369, which has been published in final form at http://onlinelibrary.wiley.com/doi/10.1002/jcaf.20369/abstract.

\title{
Financial Regulation: What Should Be Done?
}

\author{
James S. Sagner \\ School of Business, University of Bridgeport, \\ Bridgeport, CT 06601, USA \\ 2008
}


Financial Regulation: What Should Be Done?

James S. Sagner, PhD

School of Business, Metropolitan College of New York, and Sagner/Marks

The world's financial industry has been undergoing a series of dynamic transitions for at least the past two decades. Change factors include technology, globalization, nearly universal acceptance of capitalism, the ending of trade barriers, and the strategic decision by financial service companies (FSCs) to pursue apparent opportunities outside of traditional lines of business. The situation is complicated by varying approaches to regulation used in the leading economies, varying from functional regulation in the U.S. to consolidated regulation in the U.K. and Japan. This article briefly reviews the current state of financial regulation, concluding with specific comments on the successes and failures of each approach in the context of the 2007 credit crisis and the impact on future M\&A activity.

\section{U.S. Banking}

The regulation of American business did not begin until the Civil War, following decades of republican distain for federal interference with the workings of the markets 
and a priority to states' rights. ${ }^{1}$ The impetus for the involvement of the Lincoln

Administration in national regulation of banking was the exigent circumstances of the War, requiring a uniform approach to the supervision and control of the banks. ${ }^{2}$ This regulation has continued to the present day through the federal chartering of banks and the oversight of the Comptroller of the Currency (OCC).

The Federal Reserve System (FRS) was created as America's central bank in the aftermath of the Panic of 1907. ${ }^{3}$ The Glass-Steagall Act resulted from widespread banking failures at the outset of the Great Depression in the 1930s. ${ }^{4}$ This legislation prohibited commercial banks from investment banking activities as Congress sought a scapegoat for the 1929 crash, and also created the Federal Deposit Insurance Corporation (FDIC) to prevent runs on banks. Other legislation was enacted in subsequent periods, with the general intent of limiting the possibility of systemic failure.

This attitude was not reversed until the passage of the Gramm-Leach-Bliley Act of 1999 (GLB), ${ }^{5}$ the product of years of lobbying by the financial services industries, ${ }^{6}$ and was successful primarily because the federal government finally perceived the need to retain and enhance the competitiveness of U.S. financial institutions in the global economy. GLB is based on a consolidated business strategy but functional administrative

\footnotetext{
${ }^{1}$ For a brief history of U.S. regulation, see James S. Sagner, “Antitrust as Frontier Justice: Is It Time to Retire the Sheriff?" 111 Business and Society Review 37 (2006).

${ }^{2}$ National Currency Act of 1863, 12 Stat. 678; National Bank Act of 1864, 13 Stat. 99, codified as amended in various sections of 12 U.S.C.

${ }^{3}$ Federal Reserve Act of 1913, 38 Stat. 251; codified in various sections of 12 U.S.C.

${ }^{4}$ Also known as the Banking Act of 1933, 48 Stat. 162 (1933); codified in various sections of 12 U.S.C. The Banking Act of 1935, 49 Stat. 684, established the FDIC as a permanent federal agency.

5113 Stat. 1338 (1999); codified as amended in various sections of 12 and 15 U.S.C.

${ }^{6}$ The industry spent $\$ 300$ million over nearly 20 years in lobbying Congress to change the legislation (the Glass-Steagall Act of 1933) that prohibited consolidated financial services activities. Robert Kuttner,"A Requiem for Glass-Steagall," Business Week, November 15, 1999, 28.
} 
controls designed to continue the established regulatory scheme for the various activities of financial services companies. The result of this functional regulation is that diversified financial service companies may be subject to the oversight of numerous federal and state agencies, and yet not truly monitored by any regulator. ${ }^{7}$

\section{$\underline{\text { U.S. Insurance }}$}

There is no federal regulation of the insurance industry in the U.S.; instead, the states have provided varying levels of supervision to prevent abuses and to assure the maintenance of adequate resources to meet policyholder claims. Scandals and the resulting governmental investigations have addressed some of the more flagrant abuses. At the beginning of the $20^{\text {th }}$ century, New York State passed legislation to bar underwriting and other securities activities, restrict investment in stocks, and separate insurance companies from the banking industry. As New York was then the insurance center, this lead was followed by other states.

In 1945 Congress enacted the McCarran-Ferguson Act, ${ }^{8}$ which granted insurance companies immunity from the antitrust laws to the extent that they were regulated by state insurance laws. However, the exclusive position of the industry began to deteriorate with the development of competitive products that combined insurance and investment features (such as variable annuities). The loss of business to other financial services

\footnotetext{
${ }^{7}$ For example, a company originating and retaining commercial and residential mortgages has elements of banking, insurance, securities and real estate, could require the oversight the Comptroller of the Currency, the Securities and Exchange Commission, the Federal Home Loan Bank, state banking regulators and local real estate boards.

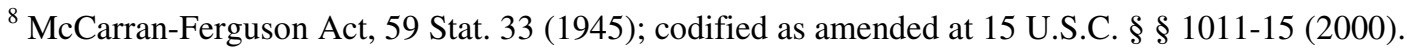


companies by the beginning of the 1990s forced industry restructuring through demutualization, ${ }^{9}$ company mergers, and expansion of product offerings.

\section{U.S. Securities Industry}

The first U.S. regulation of the securities markets resulted from the stock market crash of 1929 and the subsequent Depression. Prior to that time, stockbrokers and publicly-held companies were self regulated, primarily through the participation of respected investment bankers on corporate boards of directors. The SEC now operates on a principle of full disclosure and has regulatory authority over the statutes that now comprise the federal securities laws. ${ }^{10}$ Aside from some changes principally designed to increase regulation, the federal securities laws remain more or less in the form developed in the first two Administrations of Franklin Roosevelt.

The SEC has also become involved with entities that support the functioning of the securities markets, including accountants, credit ratings agencies, and the exchanges. Accountants in particular had maintained control over their audit procedures for some time, though the SEC would occasionally intervene when there was concern that corporate management would shop for the least strict auditor or impede the independence

\footnotetext{
${ }^{9}$ Demutualization involves the conversion of mutual ownership by policyholders to stock ownership by investors; the primary motivation is to enhance opportunities to raise external capital.

${ }^{10}$ Important statutes administered by the SEC are the Securities Act of 1933, 48 Stat. 162, 15 U.S.C. $§ 77$ a77bbbb (2000) (requiring full disclosure in connection with new offerings of securities to the public); the Securities Exchange Act of 1934, 48 Stat.891,15 U.S.C. § § 78a-78mm (2000) (creating and assigning regulatory authority to the SEC; and requiring financial reporting by public companies); the Investment Company Act of 1940, 54 Stat.797, 15 U.S.C. 80a-1 to 80a-64 (regulating investment companies, including mutual funds); and the Investment Advisors Act of 1940, 54 Stat. 847, 15 U.S.C. $\S ~ 80 b-1$ to 80b-21 (2000) (regulating and registering investment advisors).
} 
of an audit through the collateral sale of consulting services. Most recently, the Enron debacle and other accounting scandals heightened regulatory concern over the role of these entities, and the Sarbanes-Oxley Act of 2002 created a Public Company Accounting Oversight Board to oversee the auditing principles and practices of auditors. ${ }^{11}$

Most threatening to the exchanges are the electronic communication networks (ECNs), which are no more than order matching services that had no market makers. ECNs are popular with institutions because they remove intermediaries, such as the exchange specialist, from the transaction, thereby saving costs. The New York Stock Exchange, the last important auction market, responded to ECN technology in late 2005 by agreeing to merge with Archipelago Holdings. This initiative will result in an eventual conversion to electronic trading.

\section{$\underline{\text { UK - Financial Services Authority }}$}

For much of history, financial institutions in the United Kingdom relied on selfregulation and the potentially unpleasant result of official disapproval. The Bank of England's regulatory role was also as the central bank and lender of last resort. A more formal bank regulatory system was introduced in the Banking Act 1979, which was in turn replaced by a strengthened Banking Act $1987 .{ }^{12}$ The insurance industry was largely controlled by Lloyd's of London, and although shaken by scandals in the 1970s, it

\footnotetext{
${ }^{11}$ Sarbanes-Oxley Act of 2002, 116 Stat. 745; codified at 15 U.S.C. 78a et seq.

${ }^{12}$ See Heidi Mandanis Schooner and Michael Taylor, "Convergence and Competition: The Case of Bank Regulation in Britain and the United States," 20 Michigan Jl. of Int'l Law 595, 629-35 (1999); and Philip N. Hablutzel, “A Legal Sampler: British Banks' Role in U.K. Capital Markets Since the Big Bang,” 68 Chicago-Kent Law Review 365 (1992).
} 
continued to rely on self-regulation. This failed to prevent further scandals or the losses that came from a series of disasters in the 1980s. ${ }^{13}$

The moralistic regulatory approach of the London Stock Exchange was questioned after a series of scandals that began in the 1970s in the securities markets, ${ }^{14}$ leading to corrective legislation in the form of the Financial Services Act of 1986. The legislation drew heavily from the SEC regulatory model in the U.S., and, among other things, eliminated fixed commissions. Furthermore, the separation of brokers and dealers was removed in favor of competing market makers.

Various scandals, including Robert Maxwell's problems, the BCCI debacle, several insider trading cases and the crisis at Barings Bank precipitated more legislation, which created the Financial Services Authority (FSA-UK) in $1997 .{ }^{15}$ In 1998 the agency was given the authority to oversee the banks, taking that power away from the Bank of England, and it eventually became a governmental super regulator for the financial services, from securities, banking and insurance. ${ }^{16}$ The FSA-UK was also provided with expanded enforcement powers that included the right to bring actions against violators and impose sanctions. ${ }^{17}$

\footnotetext{
${ }^{13}$ Ian Kelley, "Note, Regulatory Crisis at Lloyd's of London: Reform from Within," 18 Fordham Int'l Law Jl. 1924 (1995).

${ }^{14}$ For a description of the London financial markets, see David Kynaston, The City of London (1994).

${ }^{15}$ Thomas Sims, "Single Regulators Are Catching on in Europe," Wall St. Jl. (International), Mar. 6, 2001, A14.

${ }^{16}$ The functioning of the agency is described in FSA, Introduction to the Financial Services Authority (2001).

${ }^{17}$ See, e.g., Silvia Ascarelli, “Deals \& Deal Makers: New U.K. Financial Regulator Draws Fire," Wall St. Jl., May 30, 2001, C16.
} 
Several steps were taken to unify regulation. First, a single ombudsman was to be created by the agency to handle complaints by customers in all sectors of public finance, as opposed to the various hotlines and websites for federal and state agencies in the U.S. The FSA-UK created a single Financial Services Compensation Scheme ("FSCS") for insurance, providing customers with compensation in the event of the insolvency of a financial service firm. This sharply contrasts with the U.S. system that spreads responsibility among the FDIC and separate funds for insurance companies, thrift institutions, credit unions and pension funds.

The FSA-UK is also seeking publication of comparative information disclosure for a range of financial instruments that would allow more informed investment decisions. The agency assigned one office to develop policy on issues across all financial sectors to develop a common approach to risk and capital requirements. There has been no comparable effort in the U.S., where there are separate capital requirements for insurance companies, banks, broker-dealers, and commodities futures.

In developing its regulatory approach, the FSA-UK focuses on high-risk firms, while requiring other firms to report and to comply with standards of conduct stated in its rulebook. The agency, like the SEC, has placed heavy emphasis on the supervisory responsibilities of senior corporate managers, and has begun a program of enforcement actions, imposing fines and banning the guilty from trading in London. 


\section{$\underline{\text { The Choice between Functional and Consolidated Regulation }}$}

The different areas of the financial services industry have been gradually intermingling over the last quarter of a century. The American model of functional regulation is based on the historical separation of financial services and not on their current status. The single regulator approach could permit financial regulation from the larger perspective of the strategic objectives and decisions of a financial services organization, rather than of specific product lines and operations.

Computers and telecommunications are reducing the importance of the traditional intermediation function. The Internet is turning financial services into a commodity that can be bought online, just like a book or a DVD. Utilizing technology to sell new financial products to existing customers may also be less expensive than acquiring a bricks-and-mortar entity. Depositors and borrowers can now bypass banks in favor of direct access to the capital markets to obtain higher returns not subject to transaction costs imposed by an intermediary.

There is an interesting aspect to the UK model and reminiscent of the early U.S. attitude -- the culture of avoiding governmental interference in business. ${ }^{18}$ London has learned from long experience that, while there will always be scandals and failures, each should be dealt with accordingly. This is in sharp contrast to the current American

\footnotetext{
${ }^{18}$ The interested reader may wish to review Sean Wilentz's excellent history of America in the $18^{\text {th }}$ century, The Rise of American Democracy: Jefferson to Lincoln, W.W. Norton and Company, 2005.
} 
approach to business regulation: that fraud and the misappropriation of company funds can only be prevented by draconian penalties, as in the Sarbanes-Oxley Act of 2002.

Because there will certainly be problems with and political opposition to a single regulator, the organizational solution may be to create at least two super-regulators into their logical constituencies: ${ }^{19}$

- Institutions: the functioning of financial services businesses in terms of such risk categories as-

- Insurance risk for the safety of customer funds that are on deposit with a financial services firm. This would include the segregation of customer funds and administration of account insurance (like the FDIC).

- Business risk to protect the integrity of the intermediation process used by all financial services companies. This would include assurance that adequate collateral exists for loans, that appropriate due diligence has occurred in deciding whether to establish and continue relationships with customers, and that necessary documentation exists to support financial transactions.

\footnotetext{
${ }^{19}$ Portions of the following material are based on Heidi Mandanis Schooner, "Regulating Risk Not Function," 66 University of Cincinnati Law Rev. 441 (1998), particularly 478-486
} 
- Systemic risk for the security of the financial system. This would involve uniform capital requirements, payment system regulation, and the monitoring of financial system liquidity.

- Individuals: protection of individual investors, depositors and consumers, who are too weak, uninformed and scattered to defend themselves. The securities industry has long recognized that institutions and other sophisticated market participants do not need the same regulatory protections as unsophisticated investors. ${ }^{20}$ Financial services for retail customers would be subject to regulation and the protections afforded such investors, policyholders and depositors across product lines. This includes the prevention of deceptive sales practices, and prosecution of "churning" of securities and of fraudulent profit claims.

\section{$\underline{\text { Regulation and the } 2007 \text { Credit Crisis }}$}

Although the facts and failures that caused the credit crisis of 2007 will be examined by scholars, bankers and regulators for years to come, we do know that loans were made on sub-prime residential and some commercial properties without adequate credit review. There is no question that deregulation allowed too many inadequately supervised lenders and brokers to participate in the U.S. real estate bubble supported by cheap money (i.e., low interest rates) and investor speculation.

\footnotetext{
${ }^{20}$ For example, the SEC permits the private placements of securities to qualified institutional investors without meeting the requirements of filing a prospectus and complying with agency review. Rule 144A, 55 Federal Register 17945, Apr. 30, 1990, as amended at 57 Federal Register 48722, Oct. 28, 1992.
} 
To a significant extent, securities and other financial services firms have replaced traditional bank managers, resulting in the exponential growth in potential market participants. ${ }^{21}$ As lenders resell the risk of default, the normal banker review of collateral valuation and income verification is weakened. Why bother, if you are going to sell off the loan to investors and keep the origination fees? As these investors then resell off the risks to others, no regulator really knows where the risks are.

Lenders were convinced that a "science" had been created using proprietary models that examined numerous variables on borrower behavior, like payment history, credit scores and other data. Apparently there was insufficient history on exotic loans (like adjustable-rate interest only mortgages) to accurately predict lender behavior. ${ }^{22}$ Furthermore, housing exists in a special business cycle, one that is longer than regular economic cycles while dependent on a reasonably liquid market to allow buyers to sell and buy property within a limited window of time. When sales of existing property stop, the buying of new property stops, and any forced sales due to borrower problems or lender repossessions can be at values below the loan amount.

If government oversight had followed the consolidated UK model, ${ }^{23}$ rather than the irrelevant old functional U.S. model, there is a reasonable likelihood that the regulators could have done their job in preventing this situation. Modern financial theory

\footnotetext{
${ }^{21}$ According to one source, firms like hedge funds and other non-traditional financial market providers now purchase 70\% (!) of leveraged loans, debt traditionally held by banks. Matthew Quinn and Marine Cole, "It's Hard Out There for a Bank ...," Financial Week, Aug. 20, 2007, 1, 20, at 1.

${ }^{22}$ For one review of the credit problem, see "Not So Smart," Business Week, Sept. 3, 2007, pages 30-36.

${ }^{23}$ There are other applications of the consolidated model (such as the FSA-Japan); however, a full review is beyond the scope of this article.
} 
develops at a far more rapid rate than functional regulation; what is required are superadministrative agencies to make certain that each new development or market participant is brought under a regulatory umbrella to assure the integrity of the financial markets. Specifically, regulators could have demanded fuller disclosure about the holdings of credit investors, and could then have responded with appropriate remedies (including the orderly sale of troubled loans, higher reserves against weaker credits, and updated loan documentation on borrowers.)

\section{$\underline{M \& A}$ in the Financial Services Industries}

The credit crisis has frightened investors, lenders and the financial markets, even

finally catching the attention of President Bush. ${ }^{24}$ As long as there is fear - even irrational fear - M\&A will be deferred except in situations of extreme distress (as in the purchase of a $16 \%$ share of Countrywide Financial by Bank of America for $\$ 2$ billion). Stability and M\&A activity will only return when there is adherence to appropriate lending procedures and adequate regulatory oversight. Should Congressional action lead to greater transparency of transactional and strategic risk, M\&A should eventually resume at pre-2007 levels as confidence returns to these markets.

Alternative regulatory scenarios and possible outcomes are in Figure 1.

[Insert Figure 1 about here]

\footnotetext{
${ }^{24}$ See Steven R. Weisman, "Bush Plans a Limited Intervention on Mortgages," New York Times, Aug. 31, 2007, C1, C6.
} 
While businesses cannot predict that M\&A activity will occur or what will result if it does, here are some tips to remember if your FSC is the acquirer or the acquired.

\section{[Insert Figure 2 about here]}

The financial services industry is becoming a global business, and American firms must compete with large international firms that cross-sell financial products and are subject to much lighter regulation than that found in the U.S. ${ }^{25}$ The confusion, complexity, and costs associated with functional regulators will certainly place U.S. financial institutions at a severe competitive disadvantage with European and Asian firms that operate under a unified regulatory umbrella. It may be an appropriate time to mirror the changes of GLB with a consolidated regulation model.

\footnotetext{
${ }^{25}$ The Basel Committee is currently coordinating such regulation, but its role is simply placed on top of the bank regulators in the U.S. Growth in international exchange linkages and of electronic transactions are other challenges facing these regulators.
} 
[Figure 1]

Alternative Regulatory Scenarios and Possible Outcomes

\begin{tabular}{|l|l|l|}
\hline Existing functional & Possible Agency Responsibilities & \multicolumn{1}{|c|}{ Implications for FSCs } \\
regulatory & $\begin{array}{l}\text { Securities: SEC } \\
\text { structure }\end{array}$ & No significant impact \\
\hline Consolidated & $\begin{array}{l}\text { Separance } \\
\text { regulation }\end{array}$ & institutions and individuals \\
Revised functional & $\begin{array}{l}\text { Securities: SEC } \\
\text { Banking: OCC, FRS } \\
\text { regulatory } \\
\text { structure }\end{array}$ & $\begin{array}{l}\text { Strengthened regulatory } \\
\text { oversight of high risk activities; } \\
\text { emphasis on protection for }\end{array}$ \\
& new federal regulation & individuals \\
\hline
\end{tabular}


[Figure 2]

Checklist for Companies whose FSCs are Involved in M\&A Activity

$\square$ How was past M\&A activity managed by the FSC? How were FSC customers treated? Were there more complaints about services, or was it business as usual? Did the FSC focus on its core customers, perhaps asking less profitable to leave?

$\square$ Do you maintain documentation of your current operations and of FSC activities currently used? This is important in the event that you are compelled to switch FSCs following a merger. However, some businesses do not maintain such records, with most of the documentation in Joe or Jane's head. What happens if Joe or Jane leaves and you have to reconstruct the processing flow?

$\square$ Have you identified competent FSCs in the event that a change is indicated? You should periodically scan the industry and meet with prospecting FSCs to develop a file of alternative financial providers.

$\square$ Are any of your FSCs "in play" as M\&A candidates? Do your own homework, focusing on per share market price vs. book value, published daily in the American Banker and periodically in Business Week. You should be concerned if your FSC's market-to-book ratio is well below the average for the Top 50 FSCs. A clue to a FSC not in play is a strong family or group ownership of shares. Some 
of the biggest FSCs (i.e., Citigroup) are probably too large to be acquired.

$\square$ Do you have a FSC strategy and is it periodically updated? Keep records as to credit and non-credit services used, fees paid, contact persons, problems observed and their resolution, and similar matters. Plan now for the possibility of changing FSCs. 